Państwo-Prawo-Administracja

$2(1) / 2016$

ISSN 2451-1676

DOI: http://dx.doi.org/10.21784/PPA.2016.010

ROBERT KWAŚNIEWSKI

Uniwersytet Mikołaja Kopernika w Toruniu

\title{
Problematyka oskładkowania
}

„świadczeń urlopowych" w świetle

interpretacji ZUS wydanych do

2013 r. oraz orzecznictwa sądowego

The problem of "vacation benefits" contributions

in the Social Insurance Institution (ZUS) interpretations issued until 2013 and in judicial decisions

\section{Streszczenie:}

Przedmiotem niniejszej publikacji jest analiza problematyki finansowoprawnej „świadczeń urlopowych” wypłacanych przez pracodawcę pracownikom jako dodatek do wynagrodzenia zasadniczego z tytułu wykorzystania urlopu wypoczynkowego w wymiarze 14 kolejnych dni. Celem opracowania jest ustalenie, na podstawie analizy obowiązujących przepisów, decyzji interpretacyjnych ZUS wydanych do 2013 roku oraz orzecznictwa sądowego, kiedy przychód z tytułu „świadczeń urlopowych” wliczany jest do podstawy wymiaru składek na ubezpieczenie społeczne, a kiedy wliczany być nie powinien. 


\begin{abstract}
:
This paper aims to analize the financial and judicial problems of "vacation benefits" paid by employers to employees as an addition to the basic salary when employees take their holidays in the amount of 14 consecutive days The goal of the study is to determine whether the income from "vacation benefits" should be included in the base of social security contributions based on the analysis of existing regulations, ZUS interpretative decisions issued until 2013 and the judicial decisions.
\end{abstract}

Słowa kluczowe: składki na ubezpieczenie społeczne; podstawa wymiaru składek; przychód; decyzje interpretacyjne ZUS; „świadczenia urlopowe”.

Keywords: social security contributions; contribution assessment base; income; ZUS interpretive decisions "vacation benefits".

\title{
1. Wprowadzenie
}

Przedsiębiorcy prowadzący działalność gospodarczą w Polsce na podstawie wielu obowiązujących przepisów prawnych zobowiązani są do prawidłowego wypełniania obowiązków, wśród których na szczególną uwagę zasługują te związane z regulowaniem składek na ubezpieczenie społeczne i zdrowotne. Bardzo często poruszając się w gąszczu skomplikowanych przepisów dotyczących ubezpieczeń społecznych, zastanawiają się, jak uzyskać dla siebie bezpieczeństwo i pewność w obrocie prawnym. Instrumentem, który umożliwia zapewnienie im bezpieczeństwa $w$ obrocie prawnym ${ }^{1}$, ale także pozwala na zdobycie wiedzy w zakresie wykładni przepisów prawa, jest rozwiązanie przyjęte przez ustawodawcę $\mathrm{w}$ art. 10 ustawy z dnia 2 lipca 2004 r. o swobodzie działalności gospodarczej², w którym to Zakład Ubezpieczeń Społecznych³ ${ }^{3}$ ostał zobowiązany do wydawania

1 Więcej na ten temat w: R. Kwaśniewski, Bezpieczeństwo przedsiębiorcy w sferze fiskalnej - na przykładzie decyzji interpretacyjnych ZUS, artykuł w przygotowaniu do druku.

2 Tekst jedn. Dz.U. z 2015 r., poz. 584 ze zm., dalej: u.s.d.g.

3 Dalej: ZUS. 
na pisemny wniosek przedsiębiorcy wiążących interpretacji przepisów prawa w jego indywidualnej sprawie.

Ustawa z dnia 10 lipca 2008 r. o zmianie ustawy o swobodzie działalności gospodarczej oraz o zmianie niektórych innych ustaw ${ }^{4}$ w art. 1 dokonała nowelizacji art. 10 u.s.d.g., zgodnie z którą obok możliwości uzyskania przez przedsiębiorcę interpretacji $\mathrm{w}$ jego indywidualnej sprawie co do zakresu i sposobu zastosowania przepisów, z których wynika obowiązek świadczenia przez przedsiębiorcę daniny publicznej, wprowadzono możliwość uzyskania w tej formie informacji w sprawie składek na ubezpieczenie społeczne lub zdrowotne (art. 10 ust. 1 u.s.d.g.). Przedsiębiorcy taki wniosek mogą składać do właściwego organu administracji publicznej lub państwowej jednostki organizacyjnej od 20 września 2008 roku5 .

Zatrudniając pracowników, każdy przedsiębiorca jako płatnik składek zobowiązany jest odprowadzać od wypłaconych pracownikom świadczeń, w tym wynagrodzeń i innych dodatkowych składników, składek na ubezpieczenie społeczne i zdrowotne. Pracownicy są tą grupą ubezpieczonych, której reprezentanci podlegają ubezpieczeniom społecznym w pełnym zakresie, co oznacza, że są objęci zarówno obowiązkiem ubezpieczenia emerytalnego i rentowego, jak i obowiązkiem ubezpieczenia chorobowego i wypadkowego. Aby określić, jakie kwoty składek na ubezpieczenie społeczne pracodawca jest zobowiązany ponieść, konieczne jest ustalenie podstawy wymiaru składek, którą jest kwota pieniężna dająca po przemnożeniu przez obowiązującą stopę procentową kwotę należnych składek ${ }^{6}$.

W przypadku pracowników podstawą wymiaru składek na ubezpieczenie emerytalne i rentowe, zgodnie z art. 18 ust. 1 ustawy z dnia

\footnotetext{
4 Dz.U. Nr 141, poz. 888.

5 R. Kwaśniewski, $O$ „decyzjach interpretacyjnych” dotyczących składek na ubezpieczenie społeczne, [w:] M. Wiśniewska (red.), Wyzwania gospodarcze, polityczne i społeczne w globalnej gospodarce, Włocławek 2015, s. 42.

6 P. Kostrzewa, Rozdział I. System ubezpieczeń społecznych [w:] J. Kuźniar (red.), Ubezpieczenia społeczne 2015, Warszawa 2015, s. 27-28.
} 
13 października 1998 r. o systemie ubezpieczeń społecznych ${ }^{7}$, jest przychód, o którym mowa w art. 4 pkt 9 tej ustawy. Odwołując się do ww. przepisu, ustawodawca za przychód uznaje przychody w rozumieniu przepisów o podatku dochodowym od osób fizycznych z tytułu: zatrudnienia w ramach stosunku pracy, pracy nakładczej, służby, wykonywania mandatu posła lub senatora, wykonywania pracy w czasie odbywania kary pozbawienia wolności lub tymczasowego aresztowania, pobierania zasiłku dla bezrobotnych, świadczenia integracyjnego i stypendium wypłacanych bezrobotnym oraz stypendium sportowego, a także z tytułu prowadzenia pozarolniczej działalności oraz umowy agencyjnej lub umowy zlecenia, jak również z tytułu współpracy przy tej działalności lub współpracy przy wykonywaniu umowy oraz przychody z działalności wykonywanej osobiście przez osoby należące do składu rad nadzorczych, niezależnie od sposobu ich powoływania.

Określenie tego, co stanowi, a co nie stanowi podstawy wymiaru składek, wymaga więc w pierwszym rzędzie sięgnięcia do przepisów ustawy z dnia 26 lipca 1991 r. o podatku dochodowym od osób fizycznych ${ }^{8}$. W myśl art. 12 ust. 1 ww. ustawy za przychody ze stosunku służbowego, stosunku pracy, pracy nakładczej oraz spółdzielczego stosunku pracy uważa się wszelkiego rodzaju wypłaty pieniężne oraz wartość pieniężną świadczeń $w$ naturze bądź ich ekwiwalenty bez względu na źródło finansowania tych wypłat i świadczeń, a w szczególności: wynagrodzenia zasadnicze, wynagrodzenia za godziny nadliczbowe, różnego rodzaju dodatki, nagrody, ekwiwalenty za niewykorzystany urlop i wszelkie inne kwoty niezależnie od tego, czy ich wysokość została z góry ustalona, a ponadto świadczenia pieniężne ponoszone za pracownika, jak również wartość innych nieodpłatnych świadczeń lub świadczeń częściowo odpłatnych.

Ustawodawca przewidział jednak możliwość modyfikacji podstawy wymiaru składek dla pracowników w oparciu o przepisy wy-

Tekst jedn. Dz.U. z 2015 r., poz.121 ze zm., dalej: u.s.u.s.

Tekst jedn. Dz.U. z 2012 r., poz. 361 ze zm. 
konawcze, wydane na podstawie art. 21 ustawy systemowej, zgodnie z którym „Minister właściwy do spraw zabezpieczenia społecznego określa, w drodze rozporządzenia, szczegółowe zasady ustalania podstawy wymiaru składek, z uwzględnieniem ograniczenia, o którym mowa w art. 19 ust. 1, oraz wyłączenia z podstawy wymiaru składek niektórych rodzajów przychodów". Obecnie w tym zakresie obowiązuje rozporządzenie Ministra Pracy i Polityki Socjalnej z dnia 18 grudnia $1998 \mathrm{r}$. w sprawie szczegółowych zasad ustalania podstawy wymiaru składek na ubezpieczenie emerytalne i rentowe ${ }^{9}$, które enumeratywnie wylicza rodzaje przychodów niestanowiących podstawy wymiaru składek na ubezpieczenie społeczne.

W związku z powyższym nie wszystkie świadczenia pieniężne bądź niepieniężne, które są przychodami ze stosunku pracy w świetle przepisów ustaw podatkowych, stanowić będą podstawę wymiaru składek na ubezpieczenie emerytalne i rentowe pracowników. Przykładem świadczenia pieniężnego, które nie stanowi podstawy wymiaru składek na ubezpieczenie społeczne pracownika, jest wypłacane przez pracodawcę pracownikowi świadczenie urlopowe ${ }^{10}$. I tak w myśl § 2 ust. 1 pkt 21 rozporządzenia Ministra Pracy i Polityki Społecznej z podstawy wymiaru składek na ubezpieczenie emerytalne i rentowe wyłączone zostały przychody stanowiące wartość finansowanych przez pracodawcę „świadczeń urlopowych wypłacanych na podstawie art. 3 ust. 4 ustawy z dnia 4 marca 1994 r. o zakładowym funduszu świadczeń socjalnych ${ }^{11}$, do wysokości nieprzekraczającej rocznie kwoty odpisu podstawowego określonej w tej ustawie".

Celem publikacji jest ustalenie, na podstawie analizy obowiązujących przepisów, decyzji interpretacyjnych ZUS wydanych do 2013 roku oraz orzecznictwa sądowego, kiedy przychód z tytułu „świad-

9 Tekst jedn. Dz.U. z 2015 r., poz. 2236 ze zm., dalej: rozporządzenie.

10 P. Kostrzewa, System ubezpieczeń Społecznych, [w:] J. Kuźniar (red.), Ubezpieczenia społeczne 2015, Warszawa 2015, s. 28.

11 Tekst jedn. Dz.U. z 2015 r., poz. 111 ze zm., dalej: u.z.f.ś.s. 
czeń urlopowych" wliczany jest do postawy wymiaru składek na ubezpieczenie społeczne, a kiedy wliczany być nie powinien.

\section{2. „Świadczenia urlopowe” w świetle $\S 2$ ust. 1 pkt 21 rozporządzenia}

Jak wskazał Sąd Apelacyjny w Szczecinie w wyroku z dnia 30 października 2014 r., ${ }^{12}$ zwolnienia z podstawy wymiaru składek zawarte w przepisie $\S 2$ ust. 1 pkt 1 rozporządzenia mają charakter przywileju, stanowiąc odstępstwo od zasady powszechności oskładkowania przychodów z tytułu stosunku pracy, a w konsekwencji powinny być interpretowane bez dokonywania wykładni rozszerzającej. Zgodnie z utrwalonym orzecznictwem Sądu Najwyższego ${ }^{13}$ i jednolitym stanowiskiem doktryny prawa ubezpieczeń społecznych przepisy prawa ubezpieczeń społecznych powinny być wykładane ściśle, co oznacza w zasadzie prymat dyrektyw wykładni językowej w odniesieniu do pozostałych metod wykładni, w tym wykładni systemowej i wykładni historycznej lub celowościowej14.

Analizując $\S 2$ ust. 1 pkt 21 rozporządzenia, trzeba mieć na uwadze, że wyjątków nie można interpretować rozszerzająco. „Świadczenia urlopowe" wypłacane na podstawie art. 3 ust. 4 ustawy z dnia 4 marca 1994 r. o zakładowym funduszu świadczeń socjalnych do wysokości nieprzekraczającej rocznie kwoty odpisu podstawowego zostały wyłączone na podstawie $\S 2$ ust. 1 pkt 21 rozporządzenia Ministra Pracy i Polityki Społecznej z podstawy wymiaru składek na ubezpieczenie emerytalne i rentowe.

Zasady nabywania uprawnień, sposób wyliczania i wypłacania świadczenia urlopowego regulują przepisy ustawy z dnia 4 marca 1994 r. o zakładowym funduszu świadczeń socjalnych. Świadczenie

\footnotetext{
III AUa 136/14, Legalis nr 1229702.

Wyrok SN z dnia 9 listopada 1999 r., II UKN 187/99; wyrok SN z dnia 16 sierpnia 2005 r., I UK 378/04, Baza Orzeczeń Sądu Najwyższego.

14 Wyrok SN z dnia 25 czerwca 2008 r., II UK 315/07, Baza Orzeczeń Sądu Najwyższego.
} 
urlopowe może wypłacać pracodawca, który zatrudnia według stanu na dzień 1 stycznia danego roku mniej niż 20 pracowników w przeliczeniu na pełne etaty i który nie utworzył Zakładowego Funduszu Świadczeń Socjalnych (art. 3 ust. 3 u.z.f.ś.s.). Świadczenie urlopowe, zgodnie $\mathrm{z}$ art. 3 ust. 5 u.z.f.ś.s., pracodawca wypłaca raz $\mathrm{w}$ roku każdemu pracownikowi korzystającemu w danym roku kalendarzowym z urlopu wypoczynkowego w wymiarze co najmniej 14 kolejnych dni kalendarzowych. Wypłata świadczenia urlopowego następuje nie później niż w ostatnim dniu poprzedzającym rozpoczęcie urlopu wypoczynkowego, o czym stanowi ust. 5a tego przepisu. Ustawodawca w art. 3 ust. 6 wskazuje, iż tak wypłacone świadczenie urlopowe nie podlega składce na ubezpieczenie społeczne pracowników.

Ustawodawca w art. 5 ust. 1 u.z.f.ś.s. stanowi, że Zakładowy Fundusz Świadczeń Socjalnych tworzy się z corocznego odpisu podstawowego, naliczanego w stosunku do przeciętnej liczby zatrudnionych. Wysokość świadczenia urlopowego, zgodnie z art. 3 ust. 4 tej ustawy, nie może przekroczyć rocznie kwoty odpisu podstawowego określonego $\mathrm{w}$ art. 5 ust. 2, $2 \mathrm{a}$ oraz 3 u.z.f.ś.s., odpowiednio do rodzaju zatrudnienia:

1. na jednego zatrudnionego $\mathrm{w}$ normalnych warunkach, z zastrzeżeniem poniższych punktów, 37,5\% przeciętnego wynagrodzenia miesięcznego $\mathrm{w}$ gospodarce narodowej $\mathrm{w}$ roku poprzednim lub w drugim półroczu roku poprzedniego, jeżeli przeciętne wynagrodzenie z tego okresu stanowiło kwotę wyższą (art. 5 ust. 2),

2. na jednego pracownika młodocianego, w pierwszym roku nauki $5 \%$, w drugim roku nauki $6 \%$, a w trzecim roku nauki $7 \%$ przeciętnego wynagrodzenia miesięcznego (art.5 ust. 2a),

3. na jednego pracownika wykonującego prace w szczególnych warunkach lub prace o szczególnym charakterze - w rozumieniu 
przepisów o emeryturach pomostowych, wynosi $50 \%$ przeciętnego wynagrodzenia miesięcznego (art. 5 ust. 3) ${ }^{15}$.

Przepis art. 3 ust. 4 określa jedynie maksymalną wysokość świadczenia urlopowego dla poszczególnych grup pracowników ustalaną w odniesieniu do wysokości odpisu podstawowego na Fundusz dla tych grup. Pracodawca ma także prawo do wypłacenia pracownikowi świadczenia urlopowego w wysokości niższej od opisu podstawowego naliczonego na dany rok. Wysokość świadczenia dla zatrudnionych, z wyjątkiem pracowników młodocianych, ustala się proporcjonalnie do wymiaru czasu pracy pracownika ${ }^{16}$.

Maksymalna wysokość odpisu podstawowego naliczona w 2015 roku na jednego:

1. pracownika zatrudnionego $\mathrm{w}$ tzw. normalnych warunkach wynosi - 1 093,93 zł (1/2 etatu - 546,97 zł),

2. pracownika zatrudnionego w szczególnie uciążliwych warunkach wynosi - $1458,57 \mathrm{zl}$,

3. pracownika młodocianego wynosi: w pierwszym roku nauki $145,86 \mathrm{zł}, \mathrm{w}$ drugim roku nauki $-175,03 \mathrm{zł}, \mathrm{w}$ trzecim roku nauki $-204,20 \mathrm{zł}^{17}$.

Z oskładkowania zwolnione jest „świadczenie urlopowe” wypłacane pracownikowi w wysokości ustalonej odpowiednio do rodzaju zatrudnienia i wymiaru jego czasu pracy. W razie wypłaty tego świadczenia w kwocie wyższej to od nadwyżki ponad kwotę świadczenia ustalonego zgodnie z przepisami ustawy o zakładowym funduszu świadczeń socjalnych należy naliczyć składki na ubezpieczenie społeczne i zdrowotne ${ }^{18}$.

Należy przy tym zwrócić uwagę na fakt, iż z wyłączenia z podstawy wymiaru składek na ubezpieczenie społeczne wartości

15 K. Madej, Komentarz do artykułu 18 ustawy o systemie ubezpieczeń społecznych, [w:] J. Wantoch-Rekowski (red.), Ustawa o systemie ubezpieczeń społecznych. Komentarz, Toruń-Warszawa 2007, s. 150-151.

16 D. Kosacka, B. Olszewski, Leksykon świadczeń ZUS, Wrocław 2012, s. 91.

17 Tamże, s. 92.

18 Tamże, s. 92-93. 
świadczeń urlopowych skorzystać mogą jedynie ci pracodawcy, którzy nie posiadają statusu jednostek budżetowych lub samorządowych zakładów budżetowych i zatrudniają według stanu na dzień 1 stycznia danego roku, w przeliczeniu na pełne etaty, mniej niż 20 pracowników. Przyjęcie poglądu przeciwnego musiałoby być oparte na wykładni rozszerzającej przepisów rozporządzenia Ministra Pracy i Polityki Społecznej z dnia 18 grudnia 1998 r. w sprawie szczegółowych zasad ustalania podstawy wymiaru składek na ubezpieczenia emerytalne i rentowe, które zawiera regulację stanowiącą wyjątek od generalnej zasady, iż podstawę wymiaru składek na ubezpieczenie społeczne stanowią przychody w rozumieniu przepisów o podatku dochodowym od osób fizycznych, osiągane przez pracowników u pracodawcy $\mathrm{z}$ tytułu zatrudnienia $\mathrm{w}$ ramach stosunku pracy. Stosowanie wykładni rozszerzającej nie znajduje tutaj uzasadnienia ${ }^{19}$.

Podsumowując, należy stwierdzić, że przedsiębiorca zatrudniający według stanu na dzień 1 stycznia danego roku w przeliczeniu na pełne etaty co najmniej 20 pracowników, który nie tworzy zakładowego funduszu świadczeń socjalnych, a zdecydował się na wypłacanie dla swych pracowników korzystających z urlopu wypoczynkowego specjalnego świadczenia urlopowego, zobowiązany jest odprowadzić od tych składników składki na ubezpieczenie społeczne. Wypłacone w takich warunkach świadczenie nie jest świadczeniem urlopowym, zgodnie z art. 3 ust. 4 ustawy o zakładowym funduszu świadczeń socjalnych. Wypłata tego typu świadczenia następuje na mocy postanowień regulaminu wynagradzania, nie zaś na podstawie przepisów ustawy o zakładowym funduszu świadczeń socjalnych (dotyczy to także sytuacji, gdy przepisy ww. ustawy zostały transportowane, czyli przeniesione do obowiązującego $\mathrm{u}$ danego pracodawcy układu zbiorowego pracy lub innych aktów wewnętrznych o charakterze regulaminów wynagradzania pracowników) ${ }^{20}$.

19 Taki pogląd przedstawiony został w decyzji nr 191 Oddział ZUS w Gdańsku z dnia 11 sierpnia 2011 r. (Znak: DI/100000/451/527/2011).

20 Tamże. 
W sytuacji, gdy pracodawca zatrudnia według stanu na dzień 1 stycznia danego roku mniej niż 20 pracowników w przeliczeniu na pełne etaty i nie tworzy zakładowego funduszu świadczeń socjalnych, a postanowił wypłacać „świadczenia urlopowe” pracownikom, świadczenie takie jest wyłączone z podstawy wymiaru składek na ubezpieczenie społeczne. Należy stwierdzić zatem, że przepisy ustawy o zakładowym funduszu świadczeń socjalnych nie uprawniają pracodawcy zatrudniającego co najmniej 20 osób w przeliczeniu na pełne etaty do wypłaty „świadczenia urlopowego" na podstawie przepisów tej ustawy. Oznacza to, że tak wypłacone świadczenie nie jest „świadczeniem urlopowym" w rozumieniu niniejszej ustawy, dlatego nie będzie korzystać z wyłączenia z podstawy wymiaru składek na ubezpieczenie społeczne.

Jeśli chodzi o regulowanie składek na ubezpieczenie zdrowotne, należy odnieść się do zasady określonej przez ustawodawcę w art. 81 ust. 1 ustawy z dnia 27 sierpnia 2004 r. o świadczeniach opieki zdrowotnej finansowanych ze środków publicznych ${ }^{21}$, zgodnie z którym do ustalenia podstawy wymiaru składek na ubezpieczenie zdrowotne pracowników stosuje się odpowiednio przepisy określające podstawę wymiaru składek na ubezpieczenie społeczne. W związku z tym składce na ubezpieczenie zdrowotne nie podlegają te „świadczenia urlopowe", od których nie ma obowiązku odprowadzania składek na ubezpieczenie społeczne.

\section{3. „Świadczenia urlopowe” w świetle wydanych do 2013 roku decyzji interpreta- -cyjnych Zakładu Ubezpieczeń Społecznych}

Spośród wydanych przez Zakład Ubezpieczeń Społecznych decyzji interpretacyjnych dotyczących „świadczeń urlopowych” oraz problematyki uwzględnienia bądź nieuwzględnienia ich w postawie wymiaru składek na ubezpieczenie społeczne i ubezpieczenie zdrowotne,

21 Tekst jedn. Dz.U. z 2015 r., poz. 581 ze zm. 
szczególną uwagę należy zwrócić na kilka z nich, a mianowicie na: decyzję Oddziału ZUS w Sosnowcu z dnia 2 kwietnia 2009 r.22, decyzję Oddziału ZUS w Gdańsku z 7 czerwca 2011 r.23, decyzję Oddziału ZUS w Lublinie z dnia 7 lipca 2011 r²4, decyzję Oddziału ZUS w Gdańsku z dnia 11 sierpnia $2011 \mathrm{r}^{25}$ oraz decyzję Oddziału ZUS w Lublinie $\mathrm{z}$ dnia 19 sierpnia $2011 \mathrm{r}$. $^{26}$

W decyzji z dnia 2 kwietnia 2009 r. ZUS uznał stanowisko wnioskodawcy za prawidłowe, stwierdzając, iż „świadczenia urlopowe” wypłacane pracownikom na podstawie zapisów w układzie zbiorowym pracy ze środków obrotowych firmy powinny być uwzględniane w podstawie wymiaru składek i nie ma w tym przypadku zastosowania $\S 2$ ust. 1 pkt 20 oraz 21 rozporządzenia Ministra Pracy i Polityki Społecznej w sprawie szczegółowych zasad ustalania podstawy wymiaru składek na ubezpieczenie emerytalne i rentowe.

Wnioskodawca wskazał, iż na dzień 1 stycznia 2009 r. zatrudniał 169 osób i zrezygnował w porozumieniu ze związkami zawodowymi z tworzenia zakładowego funduszu świadczeń socjalnych. Jedynie w układzie zbiorowym zawarto zapis o wypłacaniu „świadczenia urlopowego" w wysokości 42\% przeciętnego miesięcznego wynagrodzenia w gospodarce narodowej w roku poprzednim. Świadczenie to miało być wypłacane ze środków obrotowych firmy, a wnioskodawca nie stworzył funduszu na cele socjalno-bytowe.

ZUS wskazał, iż zgodnie z $§ 2$ ust. 1 pkt 21 ww. rozporządzenia wyłączone z podstawy wymiaru składek na ubezpieczenie emerytalne i rentowe jest „świadczenie urlopowe” wypłacane na podstawie art. 3 ust. 4 ustawy z dnia 4 marca 1994 r. o zakładowym funduszu świadczeń socjalnych do wysokości nieprzekraczającej rocznie kwoty odpisu podstawowego określonego $\mathrm{w}$ tej ustawie. Świadczenie takie wypłacają tylko pracodawcy nie tworzący zakładowego funduszu świad-

\footnotetext{
Znak: 380000-411/I-8/2009/NZ.

Znak: DI/100000/451/320/2011/KG.

Znak: DI/200000/451/414/2011.

Znak: DI/100000/451/527/2011.

Znak: WPI/200000/451/521/2011.
} 
czeń socjalnych zatrudniający według stanu na dzień 1 stycznia danego roku mniej niż 20 pracowników w przeliczeniu na pełne etaty. W stanie faktycznym przedstawionym przez wnioskodawcę ten przepis nie ma zastosowania, gdyż wnioskodawca zatrudnia na dzień 1 stycznia 2009 r. więcej niż 20 pracowników, a świadczenia urlopowe wypłacane są ze środków obrotowych firmy.

Zdaniem ZUS w tej sprawie nie ma także zastosowania z $\S 2$ ust. 1 pkt 20 rozporządzenia, który przewiduje wyłączenie z podstawy wymiaru składek świadczeń wypłacanych $\mathrm{z}$ funduszu utworzonego na cele socjalno-bytowe na podstawie układu zbiorowego pracy u pracodawców nietworzących zakładowego funduszu świadczeń socjalnych do wysokości nieprzekraczającej rocznie kwoty odpisu podstawowego określonej w art. 5 ust. 2 ustawy o zakładowym funduszu świadczeń socjalnych.

ZUS stwierdził, że aby zastosować powyższe wyłączenia świadczeń urlopowych z podstawy wymiaru składek, muszą być spełnione dwie przesłanki łącznie: mianowicie świadczenia muszą być wypłacane $\mathrm{z}$ funduszu utworzonego na cele socjalno-bytowe, a sam fundusz powinien być utworzony na podstawie układu zbiorowego pracy. W związku z tym, że „świadczenia urlopowe” nie są wypłacane z takiego funduszu, zdaniem ZUS muszą być one uwzględniane w podstawie wymiaru składek na ubezpieczenie społeczne i zdrowotne.

W decyzji interpretacyjnej z dnia 19 sierpnia 2011 r. ZUS uznał za nieprawidłowe stanowisko wnioskodawcy dotyczące nieuwzględnienia $\mathrm{w}$ podstawie wymiaru składek na ubezpieczenie społeczne „świadczenia urlopowego" wypłacanego pracownikom przez pracodawcę zatrudniającego na dzień 1 stycznia 2011 r. ponad 20 pracowników. Wnioskodawca wskazał, iż zatrudnia on w swojej firmie ponad 20 pracowników, a „świadczenia urlopowe” wypłaca na mocy postanowień regulaminu wynagradzania. Ponadto w spółce nie utworzono Zakładowego Funduszu Świadczeń Socjalnych. Jego zdaniem zgodnie z § 2 ust. 1 pkt 21 rozporządzenia wypłacane „świadczenia urlopowe” nie podlegają składkom na ubezpieczenie społeczne. 
Organ $\mathrm{z}$ takim rozumieniem przepisów przez przedsiębiorcę (wnioskodawcę) się nie zgodził i uznał jego stanowisko za nieprawidłowe. Z przedstawionego przez niego wniosku wynikało, że przedsiębiorca na dzień 1 stycznia $2011 \mathrm{r}$ zatrudniał ponad 20 osób, a „świadczenia urlopowe” wypłacał zgodnie z regulaminem wynagradzania. Jednocześnie przedsiębiorca zrezygnował $\mathrm{z}$ tworzenia zakładowego funduszu świadczeń socjalnych. ZUS uznał, że w tym stanie faktycznym „świadczenia urlopowe" wypłacane pracownikom przez wnioskodawcę nie będą wyłączone z podstawy wymiaru składek na podstawie $\S 2$ ust. 1 pkt 21 rozporządzenia Ministra Pracy i Polityki Społecznej z dnia 18 grudnia 1998 r. i tym samym będą stanowiły składnik podstawy wymiaru składek na ubezpieczenie społeczne.

W uzasadnieniu organ stwierdził, że zwolnienie z podstawy wymiaru składek na ubezpieczenie emerytalne i rentowe na podstawie powołanego $\S 2$ ust. 1 pkt 21 rozporządzenia dotyczy wyłącznie „świadczeń urlopowych” wypłacanych przez płatnika, który zatrudnia na dzień 1 stycznia danego roku mniej niż 20 pracowników w przeliczeniu na pełne etaty. W decyzji ZUS wskazał ponadto, że „świadczenia urlopowe" wypłacane na innej podstawie niż przepisy ustawy o zakładowym funduszu świadczeń socjalnych (np. na podstawie regulaminu wynagrodzenia) podlegają uwzględnieniu $\mathrm{w}$ podstawie wymiaru składek na ubezpieczenie społeczne.

Podobna sytuacja oraz rozstrzygnięcie przez ZUS nastąpiło w decyzji interpretacyjnej wydanej przez Oddział ZUS w Gdańsku w dniu 11 sierpnia 2011 r., w której stanowisko wnioskodawcy uznane zostało za nieprawidłowe. Wnioskodawca przedstawił podobny stan faktyczny, jak w poprzednio analizowanej decyzji. Mianowice zatrudniał on na dzień 1 stycznia 2011 r. ponad 20 pracowników w przeliczeniu na pełne etaty, nie został utworzony zakładowy fundusz świadczeń socjalnych w spółce, a „świadczenia urlopowe” wypłacane były na podstawie obowiązującego regulaminu wynagradzania. Przedsiębiorca w tym stanie faktycznym stwierdził, że wypłacanie „świadczeń urlopowych” w ten sposób nie rodzi obowiązku opła- 
cania składek na ubezpieczenie społeczne i zdrowotne i należy zastosować przepis $\S 2$ ust. 1 pkt 21 rozporządzenia Ministra Pracy i Polityki Społecznej z dnia 18 grudnia $1998 \mathrm{r}$.

ZUS nie podzielił stanowiska wnioskodawcy i podkreślił, że w sytuacji, gdy przedsiębiorca zatrudniający według stanu na dzień 1 stycznia danego roku w przeliczeniu na pełne etaty co najmniej 20 pracowników nie tworzy zakładowego funduszu świadczeń socjalnych, a zdecyduje się na wprowadzenie dla swych pracowników korzystających $\mathrm{z}$ urlopu wypoczynkowego specjalnego świadczenia, zobowiązany jest odprowadzać od tych składników składki na ubezpieczenie społeczne. Jeżeli wypłata „świadczeń socjalnych” następuje na mocy postanowień regulaminu wynagradzania, nie zaś na podstawie przepisów ustawy o zakładowym funduszu świadczeń socjalnych, to nie są one świadczeniami urlopowymi, o których mowa w art. 3 ust. 4 ustawy o zakładowym funduszu świadczeń socjalnych. ZUS wskazuje, że dotyczy to także sytuacji, gdy przepisy tej ustawy w przedmiotowym zakresie zostały transponowane do obowiązującego u danego pracodawcy układu zbiorowego pracy lub innych aktów wewnętrznych o charakterze regulaminów wynagradzania pracowników.

W uzasadnieniu ZUS wskazał ponadto, że mając na uwadze treść art. 81 ust. 1 ustawy z dnia 27 sierpnia 2004 r. o świadczeniach opieki zdrowotnej finansowanych ze środków publicznych, który wprowadza zasadę, iż do ustalenia podstawy wymiaru składek na ubezpieczenie zdrowotne pracowników stosuje się przepisy określające podstawę wymiaru składek na ubezpieczenie społeczne, należy uznać, iż „świadczenia urlopowe” wypłacane przez wnioskodawcę pracownikom na podstawie obowiązującego regulaminu wynagradzania stanowią dla pracowników również podstawę wymiaru składek na ubezpieczenie zdrowotne.

W decyzji z dnia 6 czerwca 2011 r. ZUS także uznał stanowisko przedsiębiorcy dotyczące możliwości wyłączenia z podstawy wymiaru składek na ubezpieczenie społeczne i zdrowotne wartości „świadczeń urlopowych” za nieprawidłowe. „Świadczenia urlopowe” miały 
być przekazane pracownikom przez pracodawcę $\mathrm{w}$ ramach rekompensaty za likwidację Zakładowego Funduszu Świadczeń Socjalnych na podstawie nowego Zakładowego Układu Zbiorowego Pracy obowiązującego od dnia 1 stycznia 2011 r. Ponadto wnioskodawca w zakresie wysokości i zasad przyznawania „świadczeń urlopowych” stosuje wprost przepisy ustawy z dnia 4 marca $1994 \mathrm{r}$ o zakładowym funduszu świadczeń socjalnych, więc jego zdaniem wartość tych składników nie powinna być uwzględniania w podstawie wymiaru składek i należy zastosować wyłączenie zawarte w $§ 2$ ust. 1 pkt 21 rozporządzenia.

ZUS, podobnie jak we wcześniej analizowanej decyzji, nie podzielił stanowiska wnioskodawcy i podkreślił, że w sytuacji, gdy przedsiębiorca zatrudnia według stanu na dzień 1 stycznia danego roku w przeliczeniu na pełne etaty co najmniej 20 pracowników i rezygnuje na mocy postanowień układu zbiorowego pracy z utworzenia zakładowego funduszu świadczeń socjalnych, a decyduje się na wprowadzenie dla swych pracowników korzystających z urlopu wypoczynkowego specjalnego świadczenia urlopowego, zobowiązany jest odprowadzać od tych składników składki na ubezpieczenie społeczne i zdrowotne. Wypłacone $\mathrm{w}$ takich warunkach świadczenie nie jest bowiem świadczeniem urlopowym, o którym mowa w art. 3 ust 4 ustawy o zakładowym funduszu świadczeń socjalnych. Wypłata tego typu „świadczeń urlopowych” następuje bowiem na podstawie postanowień układu zbiorowego pracy, a nie na podstawie przepisów ww. ustawy. ZUS wskazuje, że dotyczy to także sytuacji, gdy przepisy tej ustawy w przedmiotowym zakresie zostały transponowane do obowiązującego u danego pracodawcy układu zbiorowego pracy lub innych aktów wewnętrznych o charakterze regulaminów wynagradzania pracowników.

W decyzji interpretacyjnej z dnia 7 lipca 2011 r ZUS uznał za prawidłowe stanowisko wnioskodawcy $\mathrm{w}$ sprawie uwzględnienia w podstawie wymiaru składek na ubezpieczenie społeczne „świadczenia urlopowego" wypłacanego pracownikom oraz odmówił wyda- 
nia interpretacji w sprawie sposobu wypełnienia dokumentów ubezpieczeniowych. Wnioskodawca wskazał, że od 1 stycznia 2004 r. wypłaca swoim pracownikom „świadczenia urlopowe” na zasadach określonych w ustawie o zakładowym funduszu świadczeń socjalnych zgodnie z postanowieniami regulaminu wynagradzania. Spółka zatrudnia powyżej 20 pracowników. W regulaminie wskazano także, że spółka nie tworzy Zakładowego Funduszu Świadczeń Socjalnych. Zdaniem wnioskodawcy wypłacane pracownikom „świadczenia urlopowe" nie stanowią świadczeń w rozumieniu ww. ustawy. Są one świadczeniami ze stosunku pracy wynikającymi z przepisów wewnątrzzakładowych i podlegają składkom na ubezpieczenie społeczne.

ZUS w całości zgodził się ze stanowiskiem wnioskodawcy. W uzasadnieniu wskazał, że wnioskodawca wypłaca pracownikom zgodnie z regulaminem wynagradzania „świadczenia urlopowe”, a w przypadku wypłacania tych świadczeń na innej podstawie niż przepisy ustawy o zakładowym funduszu świadczeń socjalnych powoduje, iż świadczenia takie podlegają uwzględnieniu w podstawie wymiaru składek na ubezpieczenie społeczne. Ponadto zwolnienie z podstawy wymiaru składek na ubezpieczenie emerytalne i rentowe na podstawie $\S 2$ ust. 1 pkt 21 rozporządzenia Ministra Pracy i Polityki Społecznej z dnia 18 grudnia 1998 r. dotyczy wyłącznie świadczenia wypłacanego przez płatnika, który zatrudnia mniej niż 20 pracowników.

\section{Problematyka oskładkowania „świadczeń urlopowych” w świetle orzecznictwa sądowego}

Kwestia oskładkowania „świadczeń urlopowych”, wypłacanych na podstawie art. 3 ust. 4 ustawy z dnia 4 marca 1994 r. o zakładowym funduszu świadczeń socjalnych, do wysokości nieprzekraczającej rocznie kwoty odpisu podstawowego nie ma zbyt bogatego orzecznictwa sądowego. Sąd Najwyższy do tej pory nie wydał ani jednego orze- 
czenia, które dotyczyłoby problematyki oskładkowania „świadczeń urlopowych"27, co może świadczyć o tym, iż przedsiębiorcy nie mają większych problemów z rozumieniem przepisów dotyczących wyłączenia z podstawy opodatkowania „świadczeń urlopowych”, zgadzają się oni z wykładnią przyjętą przez Zakład Ubezpieczeń Społecznych w wydawanych interpretacjach i w tym zakresie nie prowadzą z ZUS-em sporów sądowych. Tytułem przykładu można wskazać jedynie na wyrok Sądu Apelacyjnego w Katowicach z dnia 23 kwietnia 2013 r.28, który udało się znaleźć, przeszukując Portal Orzeczeń Sądów Powszechnych.

W wyroku z dnia 23 kwietnia 2013 r. Sąd Apelacyjny podniósł, że zgodnie z treścią $§ 1$ rozporządzenia Ministra Pracy i Polityki Socjalnej z dnia 18 grudnia 1998 r. w sprawie szczegółowych zasad ustalania podstawy wymiaru składek na ubezpieczenia emerytalne i rentowe, zasadą jest oskładkowanie każdego przychodu pracownika. W § 1 powołanego rozporządzenia przewidziane zostały wyłączenia od tej zasady. Zgodnie z jego pkt 21, na który powołuje się skarżąca, do podstawy wymiaru nie wlicza się określonego ściśle w nim świadczenia, tj. świadczenia urlopowego wypłacanego na podstawie art. 3 ust. 4 ustawy z dnia 4 marca 1994 r. o zakładowym funduszu świadczeń socjalnych - do wysokości nieprzekraczającej rocznie kwoty odpisu podstawowego określonej w tej ustawie. Zdaniem Sądu Apelacyjnego musi to być zatem świadczenie urlopowe, które spełnia kryteria z ustawy z dnia 4 marca 1994 r. o zakładowym funduszu świadczeń socjalnych.

Sąd Apelacyjny zaznaczył również, że podstawę wymiaru składek na ubezpieczenia emerytalne i rentowe pracowników stanowi wypłacone im $\mathrm{w}$ danym miesiącu kalendarzowym wynagrodzenie wraz z tymi składnikami i świadczeniami, których z mocy § 2 cytowanego rozporządzenia Ministra Pracy i Polityki Socjalnej nie skorygowano

27 Informacja uzyskana w dniu 28 kwietnia 2016 r. drogą e-mailową od pracownika Biura Studiów i Analiz Sądu Najwyższego - Ewy Balcerzak.

28 III AUa 48/13, Portal Orzeczeń Sądów Powszechnych. 
z podstawą wymiaru składek. Aby więc świadczenia urlopowe mogły być wyłączone z podstawy wymiaru składek, nie wystarczy, aby były wypłacane $\mathrm{w}$ wysokości przewidzianej $\mathrm{w}$ art. 3 ust. 4 powyższej ustawy o zakładowym funduszu świadczeń socjalnych, zgodnie z którym pracodawcy zatrudniający mniej niż dwudziestu pracowników w przeliczeniu na pełne etaty i nieprowadzący gospodarki finansowej na podstawie przepisów o finansach publicznych mogą tworzyć zakładowy fundusz świadczeń socjalnych, ale nie są do tego zobowiązani.

W przypadku podjęcia decyzji o nietworzeniu funduszu pracodawca taki wypłaca pracownikom świadczenie urlopowe według zasad określonych w art. 3 ust. 4-5a ustawy o Funduszu. Na podstawie art. 4 ustawy układy zbiorowe pracy mogą dowolnie kształtować wysokość odpisu na fundusz, mogą również postanawiać, że fundusz nie będzie tworzony lub że świadczenie urlopowe nie będzie wypłacane. Przepisy o świadczeniu urlopowym, zgodnie z regulacją ustawową, dotyczą ściśle określonych grup pracodawców, tzn. tych, którzy zatrudniają co najmniej 20 pracowników, ale nie mniej niż 20 w przeliczeniu na pełne etaty oraz tych, którzy zatrudniają mniej niż 20 pracowników i nie są pracodawcami, o których mowa w art. 18-20 ustawy o finansach publicznych29.

Sąd Apelacyjny podkreślił, iż skoro odwołująca postanowiła, że Fundusz nie będzie tworzony (do czego miała prawo zgodnie z treścią art. 4 powyższej ustawy), postanowienia socjalne może zawierać regulamin wynagradzania. Jednak pracodawca, który w takiej sytuacji wypłaca pracownikom świadczenie urlopowe według zasad określonych w art. 3 ust. 4-5a ustawy o zakładowym funduszu świadczeń socjalnych, nie może skorzystać ze zwolnienia, o którym mowa w art. 3 ust. 6 ustawy.

29 Ustawa z dnia 27 sierpnia 2009 r. o finansach publicznych (tekst jedn. Dz.U. z 2013 r., poz. 885 ze zm.). 


\section{Podsumowanie}

„Świadczenie urlopowe” jest świadczeniem wypłacanym przez pracodawcę raz w roku każdemu pracownikowi korzystającemu w danym roku z urlopu wypoczynkowego w wymiarze co najmniej 14 kolejnych dni kalendarzowych, a wypłata następuje nie później niż w ostatnim dniu poprzedzającym rozpoczęcie tego urlopu. Jako przychód ze stosunku pracy powinna być uwzględniana w podstawie wymiaru składek na ubezpieczenie społeczne, lecz na podstawie $\S 2$ ust. 1 pkt 21 rozporządzenia Ministra Pracy i Polityki Społecznej z dnia 18 grudnia 1998 r. w sprawie szczegółowych zasad ustalania podstawy wymiaru składek na ubezpieczenie emerytalne i rentowe $\mathrm{z}$ tej podstawy wymiaru składek ustawodawca wyłączył „świadczenia urlopowe wypłacane na podstawie art. 3 ust. 4 ustawy o zakładowym funduszu świadczeń socjalnych, do wysokości nieprzekraczającej rocznie kwoty odpisu podstawowego określonej w tej ustawie"30.

Zwolnienie ze składek ZUS funkcjonuje jednak tylko do wysokości nieprzekraczającej rocznie kwoty odpisu podstawowego określonej w tej ustawie. Oskładkowaniu nie podlega więc „świadczenie urlopowe", które zostało wypłacone pracownikowi w wysokości ustalonej odpowiednio do rodzaju zatrudnienia oraz wymiaru jego czasu pracy. Niektórzy pracodawcy wypłacają pracownikom świadczenie urlopowe w kwocie wyższej. Wówczas od nadwyżki ponad kwotę określonego pułapu powinni naliczyć składki na ubezpieczenie społeczne i zdrowotne ${ }^{31}$. Ponadto „świadczenie urlopowe” powinno być wypłacane na podstawie przepisów ustawy o zakładowym funduszu świadczeń socjalnych i na warunkach określonych w tych przepisach przez ustawodawcę.

30 K. Madej, Komentarz do artykułu 18 ustawy o systemie ubezpieczeń społecznych..., s. 150.

31 Świadczenie urlopowe bez składek ZUS tylko w określonych granicach, Dodatek do Gazety Podatkowej nr 56 (993) z dnia 15 lipca 2013 r., http://www.gofin.pl/ skladki-zasilki-emerytury/17,2,109,119563,swiadczenie-urlopowe-bez-skladekzus-tylko-w-okreslonych.html. 
Podsumowując, należy stwierdzić, że przedsiębiorca zatrudniający według stanu na dzień 1 stycznia danego roku w przeliczeniu na pełne etaty co najmniej 20 pracowników, który nie tworzy zakładowego funduszu świadczeń socjalnych, a zdecydował się na wypłacania dla swych pracowników korzystających z urlopu wypoczynkowego specjalnego świadczenia urlopowego, zobowiązany jest odprowadzić od tych składników składki na ubezpieczenie społeczne. Wypłacone $\mathrm{w}$ takich warunkach świadczenie nie jest świadczeniem urlopowym, zgodnie z art. 3 ust. 4 ustawy o zakładowym funduszu świadczeń socjalnych. Wypłata tego typu świadczenia następuje na mocy postanowień regulaminu wynagradzania, nie zaś na podstawie przepisów ustawy o zakładowym funduszu świadczeń socjalnych.

W sytuacji, gdy pracodawca zatrudnia według stanu na dzień 1 stycznia danego roku mniej niż 20 pracowników w przeliczeniu na pełne etaty i nie tworzy zakładowego funduszu świadczeń socjalnych, a postanowił wypłacać „świadczenia urlopowe” pracownikom, świadczenie takie jest wyłączone z podstawy wymiaru składek na ubezpieczenie społeczne. Należy stwierdzić zatem, że przepisy ustawy o zakładowym funduszu świadczeń socjalnych nie uprawniają pracodawcy zatrudniającego co najmniej 20 osób w przeliczeniu na pełne etaty do wypłaty „świadczenia urlopowego" na podstawie przepisów tej ustawy. Oznacza to, że tak wypłacone świadczenie nie jest „świadczeniem urlopowym" w rozumieniu niniejszej ustawy, dlatego nie będzie korzystać z wyłączenia z podstawy wymiaru składek na ubezpieczenie społeczne.

Jeśli chodzi o regulowanie składek na ubezpieczenie zdrowotne, należy odnieść się do zasady określonej przez ustawodawcę w art. 81 ust. 1 ustawy z dnia 27 sierpnia 2004 r. o świadczeniach opieki zdrowotnej finansowanych ze środków publicznych, w myśl którego do ustalenia podstawy wymiaru składek na ubezpieczenie zdrowotne pracowników stosuje się przepisy określające podstawę wymiaru składek na ubezpieczenia emerytalne i rentowe tych osób. Skoro „świadczenie urlopowe”, o którym mowa wcześniej, nie stanowiło 
podstawy wymiaru składek na ubezpieczenia społeczne, to tym samym biorąc pod uwagę ww. przepis, nie będzie mogło stanowić podstawy wymiaru składki na ubezpieczenie zdrowotne.

\section{Literatura:}

Kosacka D., Olszewski B., Leksykon świadczeń ZUS, Oficyna Wydawnicza UNIMEX, Wrocław 2012.

Kostrzewa P., System ubezpieczeń Społecznych, [w:] J. Kuźniar (red.), Ubezpieczenia społeczne 2015, Wydawnictwo Wolters Kluwer, Warszawa 2015.

Kwaśniewski R., $O$ „decyzjach interpretacyjnych” dotyczących składek na ubezpieczenie społeczne, [w:] M. Wiśniewska (red.) Wyzwania gospodarcze, polityczne i społeczne w globalnej gospodarce, Wydawnictwo Państwowej Wyższej Szkoły Zawodowej we Włocławku, Włocławek 2015, str. 41-55.

Kwaśniewski R., Bezpieczeństwo przedsiębiorcy w sferze fiskalnej - na przykładzie decyzji interpretacyjnych ZUS, artykuł w przygotowaniu do druku.

Madej K., Komentarz do artykułu 18 ustawy o systemie ubezpieczeń społecznych, [w:] J. Wantoch-Rekowski (red.), Ustawa o systemie ubezpieczeń społecznych. Komentarz, Wydawnictwo TNOiK, Toruń-Warszawa 2007. 